\title{
ANALYTICAL HEAT CONDUCTION MODELS AT ARC FUSION WELDING
}

\author{
Ivan Samardžić, Ante Čikić, Marko Dunđer
}

Subject review

It is of high importance to determine the distribution of thermal fields in arc fusion welding processes due to their influence on mechanical properties and quality of welded joints. This paper presents analytical models for 2D and 3D heat conduction based on solutions of the Fourier's heat conduction differential equation. Furthermore, authors provide simplified equations for the calculation of cooling time and cooling rate for 2D and 3D heat conduction models.

Keywords: analytical models; cooling rate; cooling time; thermal fields; welding

\section{Analitički modeli vođenja topline kod elektrolučnog zavarivanja}

Pregledni članak

Određivanje distribucije temperaturnih polja kod elektrolučnog zavarivanja taljenjem je vrlo važno zbog njihovog utjecaja na mehanička svojstva i kvalitetu zavarenih spojeva. U radu se prikazuju analitički modeli za 2D i 3D vođenje topline temeljeni na rješenjima Fourierove diferencijalne jednadžbe za vođenje topline. Pored toga, autori daju pojednostavljene jednadžbe za proračun trajanja hlađenja i brzine hlađenja za $2 \mathrm{D}$ i 3D modele vođenja topline.

Ključne riječi: analitički modeli; brzina hlađenja; temperaturna polja; vrijeme hlađenja; zavarivanje

\section{Introduction}

There are various approaches to determining the distribution of thermal fields in fusion welding. They may be divided into experimental, numerical and analytical methods. Analytical models obtained on the basis of the Fourier's heat conduction differential equation, applied in common solid models and heat source models in arc fusion welding, in addition to quantitative data on the thermal field distribution in welding, provide the possibility of a clear qualitative insight into mutual influence of individual essential variables that affect the thermal field distribution in welding. This paper provides analytical solutions that describe 2D and 3D heat conduction in arc fusion welding, as well as simplified expressions used for determining the heat input within the process of designing the welding technology.

\section{The influence of thermal field distribution on the properties of a welded joint}

The influence of thermal field distribution and heat conduction in arc fusion welding may be observed through the cooling rate of individual welded joint points, i.e. through the cooling duration from e.g. $800{ }^{\circ} \mathrm{C}$ to 500 ${ }^{\circ} \mathrm{C}$, in the way presented in Fig. 1 .
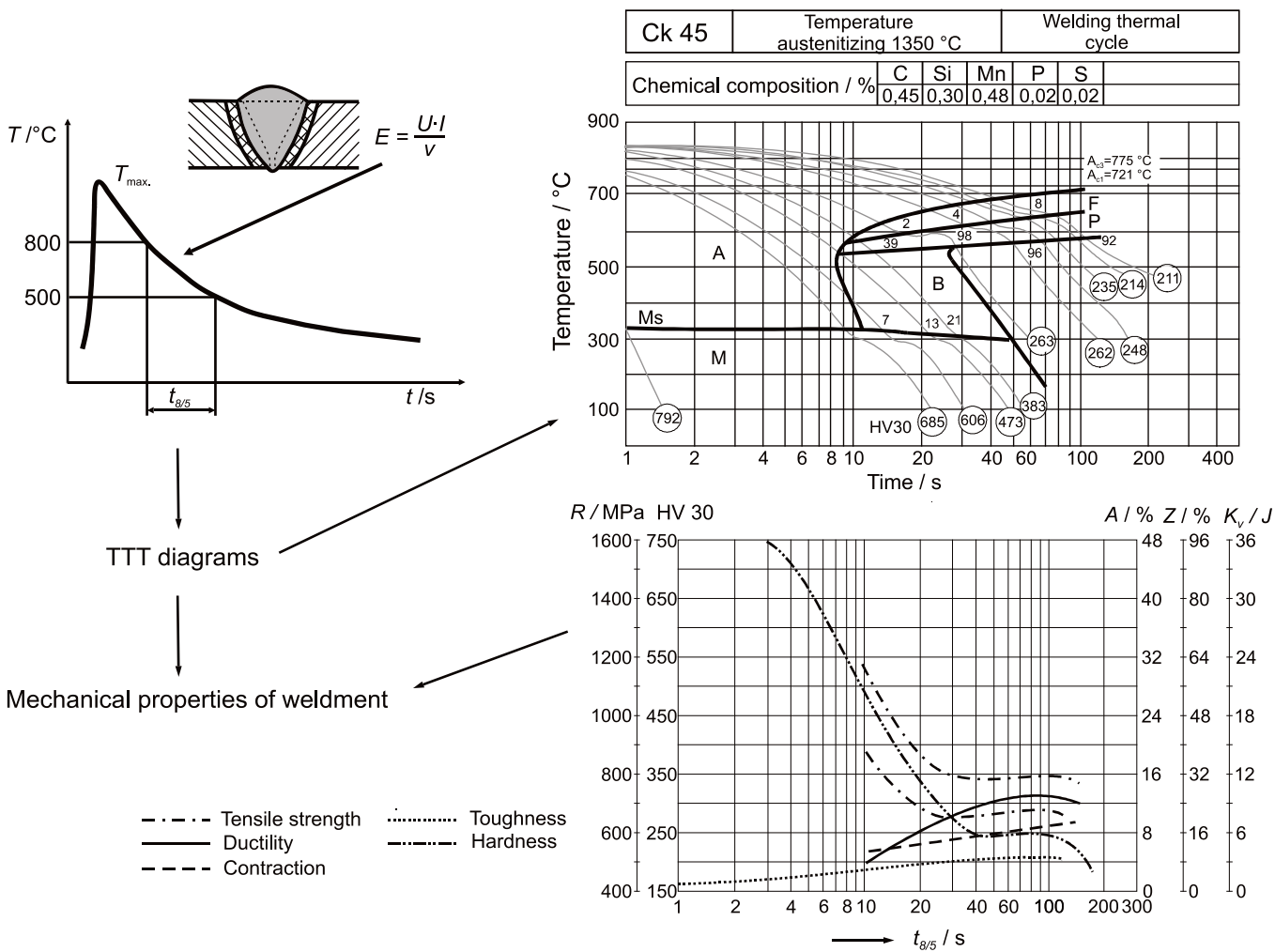

Figure 1 Qualitative influence of the cooling rate on the mechanical properties of the welded joint [1] 
The heat input in the basic material being welded heats the material in the merging point up to and above the fusion within a relatively short period of time. This is followed by cooling at a defined speed, whose consequences are mechanical properties at the joint place (strength, toughness, hardness, ...), depending on the cooling mode, i.e. the cooling rate of individual welded joint points. Due to the complexity of analytical solutions for heat conduction, frequently only the welded joint cooling cycle is considered, i.e. cooling duration from 800 ${ }^{\circ} \mathrm{C}$ to $500{ }^{\circ} \mathrm{C}$ (e.g. in common structural steel). Naturally, the cooling cycle depends on the amount of previously input heat, physical properties of materials $(\lambda, c, \rho, a)$, shape and dimensions of the material being welded and other variables of influence.

\section{Solid models and heat source models in arc fusion welding}

Solid shape and heat source shape, in addition to thermal and physical properties of materials and conditions for heat transfer into the environment, represent the main influential factors of heat expansion during welding. Mathematical models for determining thermal fields in welding, as used in this paper, were obtained under the assumption that simplified solid and heat source shapes are used, as the change of physical properties depending on the temperature was not included. Solid shapes that in practice appear in various combinations mostly refer to the following (Figs. 2, 3, 4 and 5):

a) Semi-infinite solid. Dimensions in directions $\mathrm{O} x, \mathrm{O} y$ and $\mathrm{O} z$ are large enough for them to be assumed as infinite. Heat flow, i.e. heat conduction is threedimensional. $\left(\frac{\partial T}{\partial x} \neq 0, \frac{\partial T}{\partial y} \neq 0, \frac{\partial T}{\partial z} \neq 0\right)$.

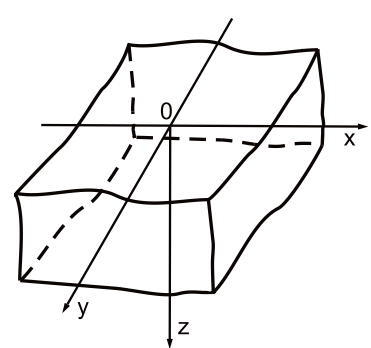

Figure 2 Semi-infinite solid model for heat conduction in welding $[1,2]$

b) Flat layer. It infinitely expands in directions $\mathrm{O} x$ and $\mathrm{O} y$, while in the direction $\mathrm{O} z$ it is calculated with a finite sheet metal dimension $\delta$. Temperatures along sheet metal thickness are not equal. Heat conduction is threedimensional $\left(\frac{\partial T}{\partial x} \neq 0, \frac{\partial T}{\partial y} \neq 0, \frac{\partial T}{\partial z} \neq 0\right)$.

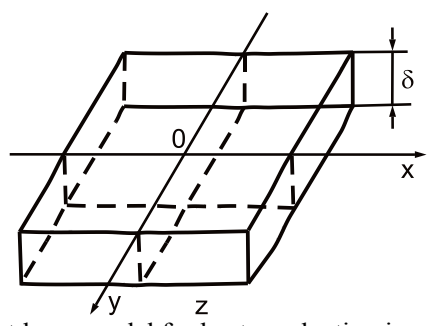

Figure 3 Flat layer model for heat conduction in welding [1, 2] c) Thin sheet metal. It is assumed that the temperature along sheet metal thickness is the same - the distribution of thermal field is the same on both sides of sheet metal. Heat conduction is two-dimensional. This temperature distribution is obtained in butt welding of thin sheet metal or in one-side welding in a single motion. $\left(\frac{\partial T}{\partial x} \neq 0, \frac{\partial T}{\partial y} \neq 0, \frac{\partial T}{\partial z}=0\right)$.

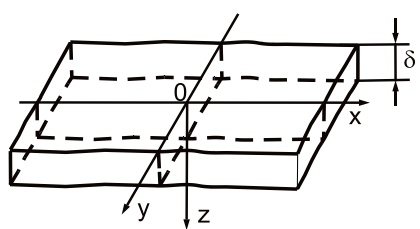

Figure 4 Thin sheet metal model for heat conduction in welding [1, 2]

d) $\mathrm{A}$ rod is an elongated solid in the direction $\mathrm{x}$ with equal temperatures in each cross-section, which results in linear heat flow in the elongated direction $\left(\frac{\partial T}{\partial x} \neq 0, \frac{\partial T}{\partial y}=\frac{\partial T}{\partial z}=0\right)$.

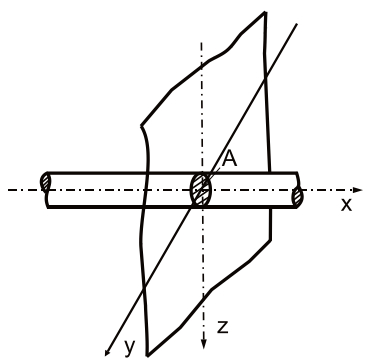

Figure 5 A rod model for heat conduction in welding $[1,2]$

Heat source shapes are divided according to the character of energy distribution in space, according to temporal action etc. (fixed and movable, ...).

According to the character of energy distribution in space, the following heat sources may be distinguished:

- point heat source in which energy is concentrated in a single point, instead of within the heating circle,

- line heat source in which energy is concentrated in a single line,

- planar heat source in which energy is concentrated in a single plane,

- volume heat source in which energy is concentrated in a given volume.

According to temporal action, the following heat sources may be distinguished: momentary, permanent, of variable intensity.

\section{Analytical models of heat conduction in welding}

Starting from the universal differential Eq. (1), models were derived that describe the effect of momentary and movable heat sources on individual models of solids being welded.

$$
\frac{\partial T}{\partial t}=a \cdot\left(\frac{\partial^{2} T}{\partial x^{2}}+\frac{\partial^{2} T}{\partial y^{2}}+\frac{\partial^{2} T}{\partial z^{2}}\right)
$$

whereat: $a$-coefficient of thermal diffusion $\mathrm{m}^{2} / \mathrm{s}$. 
This is a second order homogenous partial linear differential equation of parabolic type that provides the connection between the temperature change rate of a given point and the temperature distribution in the environment of that point.

If a workpiece is influenced by a heat source $F(x, y, z, t)$ and simultaneously heat transfer from a metal object to its environment occurs, the heat conduction Eq. (1) will have the following form:

$$
\frac{\partial T}{\partial t}=a \cdot\left(\frac{\partial^{2} T}{\partial x^{2}}+\frac{\partial^{2} T}{\partial y^{2}}+\frac{\partial^{2} T}{\partial z^{2}}\right)+\frac{1}{\rho \cdot c} \cdot F(x, y, z, t)-b \cdot T,
$$

whereat: $c, \lambda, \rho$ - material's physical properties; $b-$ coefficient of temperature drop intensity due to heat transfer from the object into the environment, $s^{-1}$.

The differential Eq. (1) resulted in solutions for cooling upon the action of a fixed momentary (impulse) heat source for common combinations of solid shape and the shape of fixed heat sources.

\section{Flat source in an infinite rod: [2]}

$$
T(x, t)-T_{0}=\frac{\frac{Q}{A}}{2 \cdot c \cdot \rho \cdot \sqrt{\pi \cdot a \cdot t}} \cdot \exp -\left(\frac{x^{2}}{4 \cdot a \cdot t}\right),
$$

\section{Line source in infinite sheet metal: [2]}

$$
T(r, t)-T_{0}=\frac{\frac{Q}{\delta}}{2 \cdot \rho \cdot(2 \cdot \sqrt{\pi \cdot a \cdot t})^{2}} \cdot \exp -\left(\frac{r^{2}}{4 \cdot a \cdot t}\right),
$$

Point source in an infinite object: [2]

$$
T(x, t)-T_{0}=\frac{Q}{c \cdot \rho \cdot(2 \cdot \sqrt{\pi \cdot a \cdot t})^{3}} \cdot \exp -\left(\frac{R^{2}}{4 \cdot a \cdot t}\right),
$$

The most frequently used heat sources in welding are movable heat sources of defined power and movement rate. Under the assumption that the coordinate system is movable and that its origin is always located in the middle of the heat source, some simplified expressions may be derived that describe the effect of movable heat sources on common solid models in welding. In the text to follow the classification of common solid models and models of movable heat sources for welding is provided, as well as the calculation mode of non-stationary thermal field, using the equations for quasi-stationary thermal field and the corrective temporal-spatial member, for common solid models and movable heat sources.

\subsection{Movable line heat source - thin flat plate}

The effect of a movable line heat source on a thin flat layer is described by the Eq. (6) in movable coordinate system $[1,3]$ :

$$
\begin{aligned}
& T(x, t)-T_{0}=\psi_{2} \cdot \frac{q}{2 \cdot \pi \cdot \lambda \cdot \delta} \cdot \exp \left(-\frac{v \cdot x}{2 \cdot a}\right) . \\
& \cdot K_{0}\left[r \cdot \sqrt{\left(\frac{v}{2 \cdot a}\right)^{2}+\left(\frac{2 \cdot \alpha}{a \cdot c \cdot \rho \cdot \delta}\right)}\right],
\end{aligned}
$$

After the initiation of the welding process, stepwise thermal saturation occurs, i.e. the amounts of input and output heat are balanced. After a sufficiently long period of welding time, the so-called assumed quasi-stationary thermal field is recovered. In theory, an infinite period of time would be necessary for reaching stationary state.

An example of a quasi-stationary thermal field (heat saturation factor $\Psi_{2}=1$, i.e. for quasi-stationary heat conduction state) that developed due to the influence of a movable line heat source with energy $q / v=4184 \mathrm{~J} / \mathrm{mm}(v$ $=1 \mathrm{~mm} / \mathrm{s}$ ), on thin flat sheet metal, is shown in Fig. 6 .

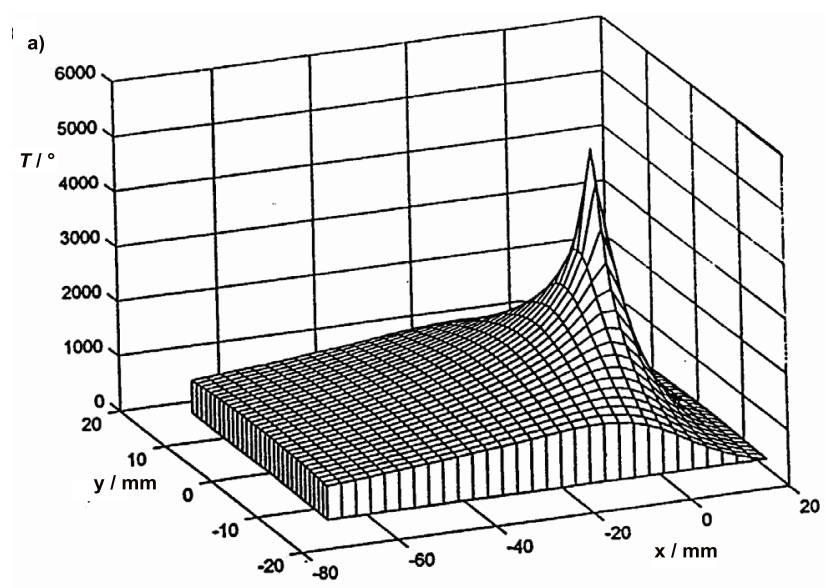

b) $\mathrm{y} / \mathrm{mm}$
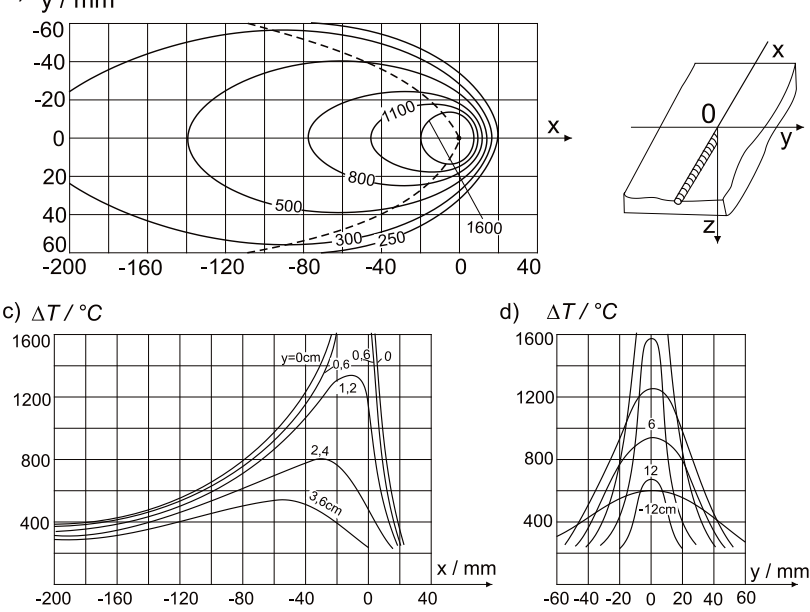

Figure 6 Quasi-stationary thermal field resulting from the influence of a movable line heat source OO', along thin sheet metal of thickness amounting to $10 \mathrm{~mm}$ in the direction of the $\mathrm{x}$ axis. $(q / v=4184 \mathrm{~J} / \mathrm{mm}$; $a=10 \mathrm{~mm}^{2} / \mathrm{s} ; \lambda=0,042 \mathrm{~W} / \mathrm{mm}^{\circ} \mathrm{C} ; b=0,00281 / \mathrm{s}$ and $\alpha=33,4 \times 10^{-6}$ $\left.\mathrm{J} / \mathrm{mm}^{2} \mathrm{~s}^{\circ} \mathrm{C}\right)[3,4]:$ a) Spatial representation of thermal field distribution $(x=-70 \mathrm{~mm}$ to $20 \mathrm{~mm}$ with the increment amounting to $3 \mathrm{~mm}, y=$

$-15 \mathrm{~mm}$ to $15 \mathrm{~mm}$ with the increment amounting to $1 \mathrm{~mm}$ ); b)

Isotherms on the plate surface in the $x y$ plane and the curve representing maximum temperatures (dashed line); c) Temperature distribution in the $x z$ plane, for the value $y=$ const.; d) Temperature distribution in the $y z$ plane, for the value $x=$ const. 


\subsection{Movable point heat source on a flat plate $[1,3]$}

$$
\begin{aligned}
& \Delta T(x, r, t)=\psi_{2} \cdot \frac{q}{2 \cdot \pi \cdot \lambda \cdot \delta} \cdot \exp \left(-\frac{v \cdot x}{2 \cdot a}\right) \\
& \cdot\left\{K_{0}\left(\frac{v \cdot r}{2 \cdot a}\right)+2 \cdot \sum_{n=1}^{\infty} \cos \left(\frac{n \cdot \pi \cdot z}{\delta}\right) \cdot K_{0}\left[r \cdot \sqrt{\left(\frac{v}{2 \cdot a}\right)^{2}+\left(\frac{\pi \cdot n}{\delta}\right)^{2}}\right]\right\},
\end{aligned}
$$

An example of a quasi-stationary thermal field (heat saturation factor $\psi_{3}=1$, i.e. for quasi-stationary heat conduction state) that developed due to the influence of a movable point heat source with energy $q / v=4184 \mathrm{~J} / \mathrm{mm}$ $(v=1 \mathrm{~mm} / \mathrm{s})$, on a flat layer of thickness amounting to 20 $\mathrm{mm}$, is shown in Fig. 7.
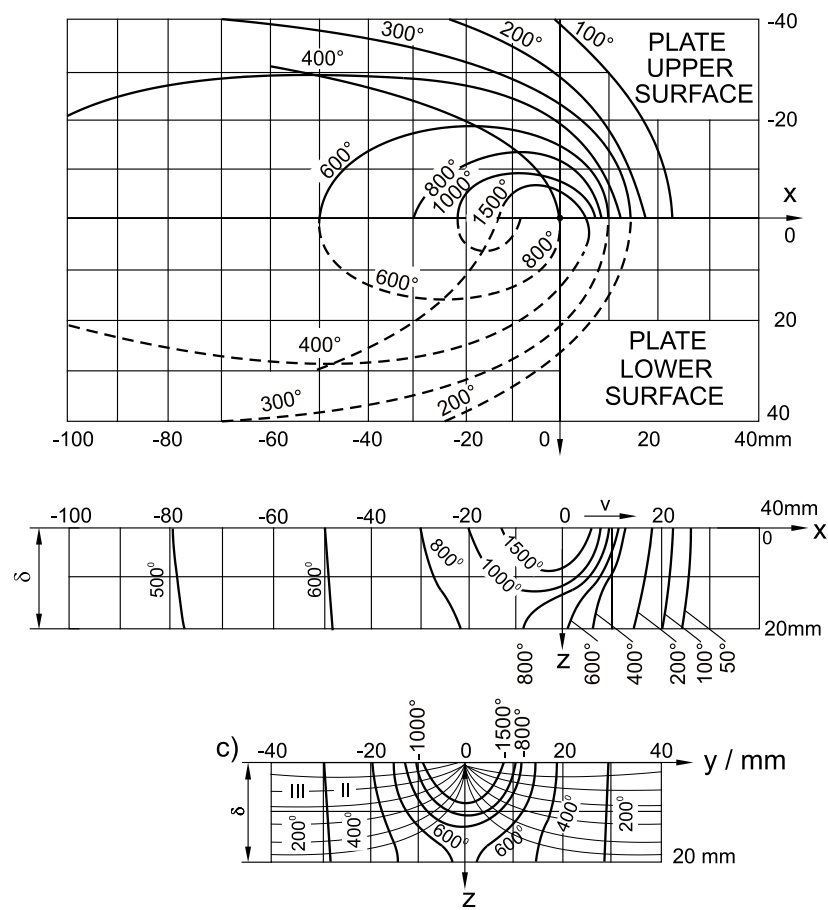

Figure 7 Quasi-stationary thermal field resulting from the influence of a point heat source at the rate $v$, on a flat layer of thickness amounting to $20 \mathrm{~mm}$ in the direction of the $\mathrm{x}$ axis. $(q / v=4184 \mathrm{~J} / \mathrm{mm}, \delta=20$ $\mathrm{mm}, a=10 \mathrm{~mm}^{2} / \mathrm{s}, \lambda=0,042 \mathrm{~W} / \mathrm{mm}^{\circ} \mathrm{C}$ ) [3, 4]: a) Isotherms and curves representing maximum temperatures on the upper $(z=0)$ - full isotherms and lower $(z=\delta)$ - dashed isotherms, sheet metal surface; b) Isotherms in vertical section $x \mathrm{O} z$; c) Isotherms and heat flow lines in cross-section $y \mathrm{O} z$.

\subsection{Movable point heat source - semi-infinite solid $[1,3]$}

The Eq. (8) describes the effect of the movable point source on a semi-infinite solid:

$$
\Delta T(x, R, t)=\psi_{3} \cdot \frac{q}{2 \cdot \pi \cdot \lambda \cdot R} \exp \left[-\frac{v \cdot(x+R)}{2 \cdot a}\right]
$$

Further simplification of these equations would be possible if these were cases of welding with high-speed and high-efficient heat sources, i.e. if the movement rate of a heat source tended to infinity, but in the way that the $q / v$ ratio remained constant. In such cases temperature gradients in the direction of the $y$ and $z$ axes are significantly higher than in the direction of the $x$ axis, the direction of the heat source movement.
This fact significantly simplifies the solution form in relation to the Eqs. (6, 7 and 8$)$, so with heat dissipation towards the environment being neglected, the aforementioned solutions take simpler forms.
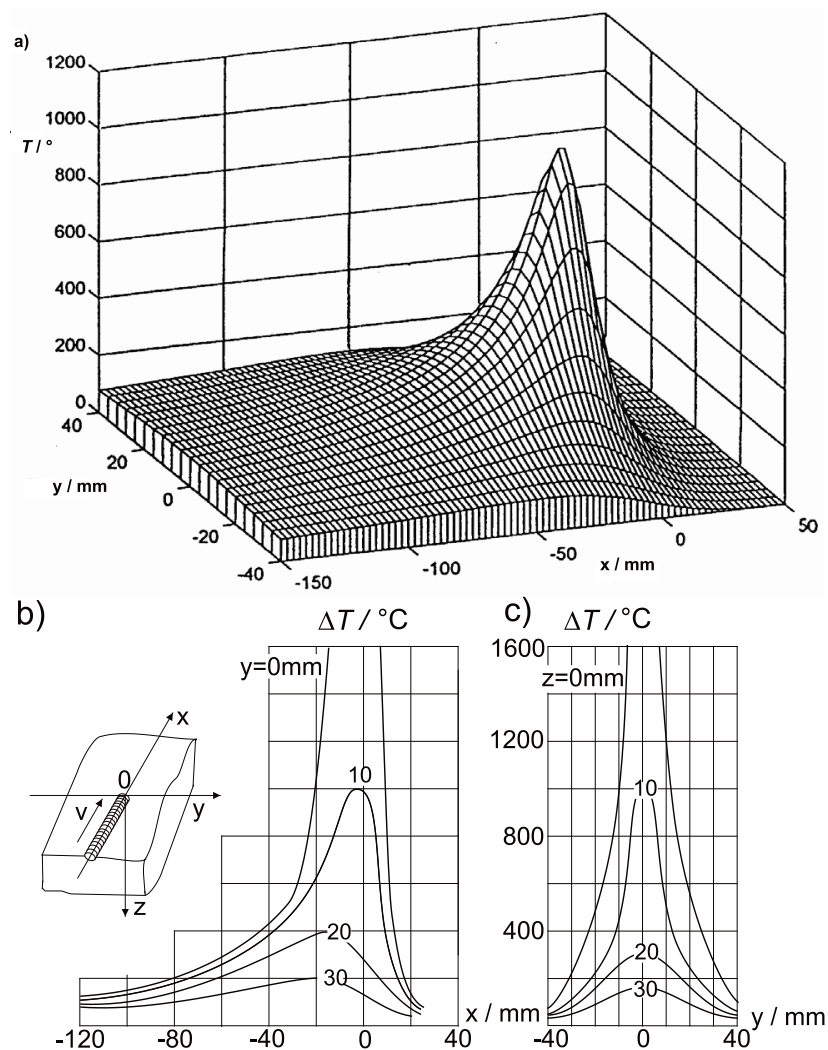

d) $\mathrm{mm}$

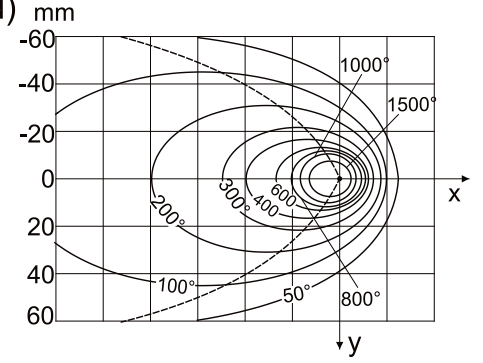

e) $\mathrm{mm} 1500^{\circ} 1000^{\circ}$

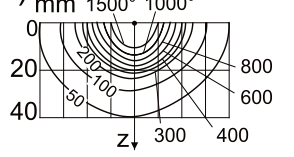

Figure 8 Quasi-stationary thermal field resulting from the influence of a point heat source on a semi-infinite solid in the direction of the $x$ axis. $\left(q / v=4184 \mathrm{~J} / \mathrm{mm} ; a=10 \mathrm{~mm}^{2} / \mathrm{s} ; \lambda=0,042 \mathrm{~W} / \mathrm{mm}^{\circ} \mathrm{C}\right)[3,4]:$ a) Spatial representation of the thermal field distribution at $z=10 \mathrm{~mm}$ below sheet metal surface; b) Isotherms on the surface in planes $y=$ const., $(x \mathrm{Oz})$; c) Temperature distribution in planes $x=$ const., $(y \mathrm{O} z) ; \mathrm{d})$ Temperature distribution in the plane $x \mathrm{O} y$ and the curve representing the maximum temperatures (dashed lines); e) Isotherms and heat flow lines in the plane $y \mathrm{O} z(x=0)$

For the case of welding with a high-speed, highefficient flat thin plate source (2D), the following equation is valid:

$$
\Delta T(y, t)=\frac{\frac{q}{v}}{v \cdot \delta \cdot \sqrt{4 \cdot \pi \cdot \lambda \cdot \delta \cdot t}} \exp \left(-\frac{y^{2}}{4 \cdot a \cdot t}\right)
$$

while the solution for the limit state of heat expansion in a one-sided limit solid (3D), it is represented by the following equation: 


$$
\Delta T(y, t)=\frac{\frac{q}{v}}{2 \cdot \pi \cdot \lambda \cdot v \cdot t} \exp \left(-\frac{r^{2}}{4 \cdot a \cdot t}\right),
$$

In Eqs. (9) and (10) as time $t$ one considers the time in which a heat source passes along the plane in which the point is momentarily located for which temperature is calculated.
From these equations it is possible to calculate the cooling rate at a given temperature or cooling time in e.g. the temperature interval from 800 to $500{ }^{\circ} \mathrm{C}\left(t_{8 / 5}\right)$.

Cooling rates of a welded joint at a selected temperature $T$ are represented by expressions (11) for a 2D heat conduction model and (12) a 3D heat conduction.

$$
w=2 \cdot \pi \cdot \lambda \cdot \rho \cdot c \frac{\left(T-T_{0}\right)^{3} \cdot \delta^{2}}{\left(\frac{q}{v}\right)^{2}}
$$

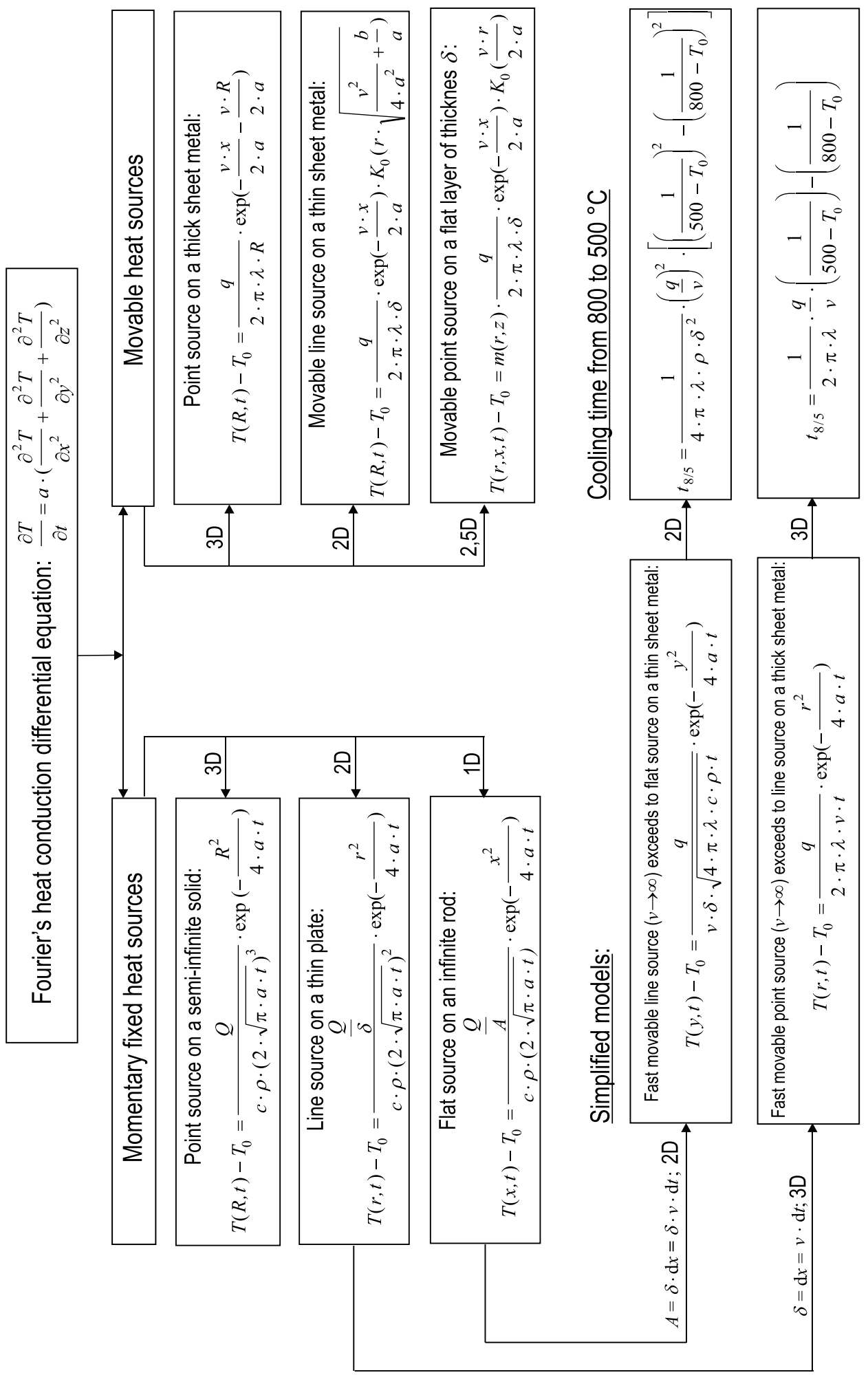

Figure 9 Equations that describe heat conduction models in arc fusion welding 


$$
w=2 \cdot \pi \cdot \lambda \frac{\left(T-T_{0}\right)^{2}}{\frac{q}{v}} .
$$

Cooling time for a simplified 2D model in the temperature interval from 800 to $500{ }^{\circ} \mathrm{C}$ for the middle of the welded joint $y=0$ may be calculated by the following Eq. (13):

$$
t_{8 / 5}=\frac{1}{4 \cdot \pi \cdot \lambda \cdot \rho \cdot c}\left(\frac{q}{v}\right)^{2} \cdot \frac{1}{\delta^{2}}\left[\left(\frac{1}{500-T_{0}}\right)^{2}-\left(\frac{1}{800-T_{0}}\right)^{2}\right],
$$

Cooling time for a simplified 3D model in the temperature interval from 800 to $500{ }^{\circ} \mathrm{C}$ for the middle of the welded joint $r=0$ may be calculated by the following Eq. (14):

$$
\Delta t_{8 / 5}=\frac{1}{2 \cdot \pi \cdot \lambda} \cdot \frac{q}{v} \cdot\left[\left(\frac{1}{500-T_{0}}\right)-\left(\frac{1}{800-T_{0}}\right)\right],
$$

In the SEW standard [5], as in other sources [6, 7, 8], Eqs. (13) and (14) are adapted to practical calculation of the welded joint cooling time in the temperature interval from 800 to $500{ }^{\circ} \mathrm{C}\left(t_{8 / 5}\right)$. By solving the Eqs. (13) and (14) according to $E_{\mathrm{ef}}=q / \mathrm{v}$, heat input may be obtained that is to be brought to a material by means of welding in order to achieve a suitable cooling rate, i.e. cooling time from 800 to $500{ }^{\circ} \mathrm{C}$ and desired mechanical properties of the welded joint.

For a 2D heat conduction model, thermal input is defined by Eq. (15),

$$
E_{\mathrm{ef}}=\frac{q}{v}=\sqrt{\frac{4 \cdot \pi \cdot \lambda \cdot c \cdot \rho \cdot \delta^{2} \cdot t_{8 / 5}}{\left(\frac{1}{500-T_{0}}\right)^{2}-\left(\frac{1}{800-T_{0}}\right)^{2}}},
$$

and for a 3D model using Eq. (16):

$$
E_{\mathrm{ef}}=\frac{q}{v}=\frac{2 \cdot \pi \cdot \lambda \cdot t_{8 / 5}}{\frac{1}{500-T_{0}}-\frac{1}{800-T_{0}}},
$$

Heat conduction model is determined based on the border thickness, obtained by setting equal the Eqs. (15) and (16) and solving them in the $\delta$ variable. In this way the Eq. (16) for border thickness $\delta_{\mathrm{gr}}$ is obtained:

$$
\delta_{\mathrm{gr}}=\sqrt{\frac{\frac{q}{v}}{2 \cdot \rho \cdot c} \cdot\left(\frac{1}{500-T_{0}}+\frac{1}{800-T_{0}}\right)},
$$

If $\delta>\delta_{\mathrm{gr}}$, the equation for 2D heat conduction is used, while if $\delta<\delta_{\mathrm{gr}}$, the equation for 3D heat conduction is used.

Fig. 9 shows the most significant equations that describe heat conduction models in arc fusion welding.

\section{Conclusion}

Analytical solutions of the Fourier's heat conduction differential equation, as applied to common solid models and heat source models in arc fusion welding processes, result in practical solutions that provide the possibility of a qualitative insight into mutual influences between individual variables and individual influence of each variable on the thermal field distribution in welding. The accuracy of analytical models presented in this paper is reduced as one approaches the middle of the welded joint, i.e. the origin of the coordinate system. However, simplified formulae for calculating thermal input and cooling time from 800 to $500{ }^{\circ} \mathrm{C}$ are very practical, so they are relatively frequently used in specialist literature. Such models are suitable for combining with numerical methods that, in addition to appropriate boundary conditions, may result in more precise calculations of thermal field distribution in welding.

\section{References}

[1] Rykalin, N. N. Berechnung der Warmevorgange beim Schwissen, VEB Verlag Technik, Berlin, 1957.

[2] Lukačević, Z. Zavarivanje. Strojarski fakultet u Slavonskom Brodu, Sveučilište u Osijeku, 1996.

[3] Samardžić, I. Doprinos pouzdanosti zavarenih spojeva. Disertacija, Tehnički fakultet Sveučilišta u Rijeci, 1996.

[4] Dunđer, M. Utjecaj brzine hlađenja na tvrdoću i žilavost. Doctoral thesis, Fakultet strojarstva i brodogradnje u Zagrebu, 2005.

[5] Stahl Eissen Werkstoffblatter (SEW 088), October 1993.

[6] Samardžić, I.; Čikić, A.; Dunđer, M. Accelerated weldability investigation of TStE 420 steel by weld thermal cycle simulation. // Metalurgija. 52, 4(2013), pp. 461-464.

[7] Friedman, E. Thermomechanical analysis of the welding process using the finite element method. // Journal of Pressure Vessel Technology. 97, 3(1975), pp. 206-213. DOI: $10.1115 / 1.3454296$

[8] Služalec, A. Theory of Thermomechanical Processes in Welding, Springer Netherlands, 2005. DOI: 10.1007/1-40202991-8

\section{Codes and units}

$\alpha$ - heat transfer coefficient, $\mathrm{J} /\left(\mathrm{mm}^{2} \mathrm{~s}{ }^{\circ} \mathrm{C}\right)$

$\delta$ - metal thickness, mm

$\lambda$ - heat conductivity coefficient, $\mathrm{J} /\left(\mathrm{mm} \mathrm{s}^{\circ} \mathrm{C}\right)$

$\rho-$ material specific weight, $\mathrm{kg} / \mathrm{m}^{3}$

$\eta$ - efficiency of electric arc heat consumption

$\psi_{2}, \psi_{3}-$ heat saturation factor for 2-dimensional and 3-

dimensional heat conduction state, -

$A-$ area, $\mathrm{mm}^{2}$

$A_{5}$ - ductility, \%

$a$ - coefficient of thermal diffusion $\mathrm{m}^{2} / \mathrm{s}$

$b$-coefficient of temperature drop intensity due to heat transfer from the object into the environment, $s^{-1}$

$c$ - specific heat capacity, $\mathrm{J} /\left(\mathrm{s} \mathrm{mm}^{\circ} \mathrm{C}\right)$

$Q$ - amount of heat, $\mathrm{J}$

$E_{\text {ef }}=q / v-$ heat input, $\mathrm{J} / \mathrm{mm}$

$H V$ - hardness in Vickers

$K_{\mathrm{V}}$ - impact energy (toughness), J

$I$ - electric arc current, A

$l_{n}(X), l_{-n}(X)-$ Bessel functions 
$K_{0}$ - modified Bessel function of zero order, second kind

$K_{n}(X)$ - MacDonald function

$q=U \cdot I \cdot \eta-$ effective power in in electric arc, $\mathrm{W}$

$r, R$ - radius vector, $\mathrm{mm}$

$\Delta T$ - temperature difference, ${ }^{\circ} \mathrm{C}$

$T_{0}$ - preheating temperature or initial material temperatures, ${ }^{\circ} \mathrm{C}$

$x, y, z$ - coordinate axes

$t_{8 / 5}-$ cooling time between $800{ }^{\circ} \mathrm{C}$ and $500{ }^{\circ} \mathrm{C}$, s

$v$ - welding speed, $\mathrm{mm} / \mathrm{s}$

$U$ - electric arc voltage, $\mathrm{V}$

$Z$ - contraction, $\%$

\section{Authors' addresses}

Ivan Samardžić, PhD, Full Professor, graduate engineer Faculty of Mechanical Engineering in Slavonski Brod,

J. J. Strossmayer University of Osijek,

Trg I. B. Mažuranić 2, Slavonski Brod, Croatia

E-mail: isamar@sfsb.hr

Ante Čikić, PhD, Associate Professor, graduate engineer

Technical College in Bjelovar

Trg E. Kvaternika 4, 43000 Bjelovar, Croatia

E-mail: acikic@vtsbj.hr

Marko Dunder, PhD, Full Professor, graduate engineer

University of Rijeka, Department of Polytechnics,

Sveučilišna avenija 4, Rijeka, Croatia

E-mail: marko.dundjer@uniri.hr 